\title{
Comparison of Compressive and Tensile Strengths of Dry-Cast Concrete with Ordinary Portland and Portland Pozzolana Cements
}

\author{
Rasyiid Lathiif Amhudo ${ }^{a}$, Tavio ${ }^{\text {b* }}$, I Gusti Putu Raka ${ }^{\mathrm{b}}$ \\ ${ }^{a}$ Master's Candidate, Department of Civil Engineering, Institut Teknologi Sepuluh Nopember (ITS), Surabaya, Indonesia. \\ ${ }^{b}$ Professor, Department of Civil Engineering, Institut Teknologi Sepuluh Nopember (ITS), Surabaya, Indonesia .
}

Received 21 May 2018; Accepted 28 July 2018

\begin{abstract}
Concrete is the most widely used construction material in the world. Along with the increasing economic needs in the development of construction, precast technology has become a primary solution that leads to the industrialization. The use of precast concrete system offers several advantages, such as rapid erection, higher product quality, lower project cost, better sustainability, and improved occupational health and safety. In general, there are two casting methods used in concrete placement, namely wet- and dry-castings. The dry-cast concrete has also been used for its advantages particularly in precast concrete industries, e.g. its rapid hardening time for fast mold removal (it significantly increases the plant productivity). The use of Portland Pozzolana Cement (PPC) as a replacement to Ordinary Portland Cement (OPC) has become increasingly popular for the past decade. Hence, its application in dry-cast method needs to be further investigated for its mechanical properties such as its compressive and splitting tensile strengths. An experimental work was carried out to examine the properties of dry-cast concrete using both types of cements (PPC and OPC). The development of its compressive strength was also monitored at $1,7,14,21,28$, and 56 days of age. The splitting test was conducted to describe the tensile strength of dry-cast concrete. The observation of crack and failure behaviour of all concrete specimens were also carried out.
\end{abstract}

Keywords: Compressive Strength; Dry-Cast Concrete; OPC; PPC; Precast Concrete; Splitting Test; Tensile Strength; Wet-Cast Concrete.

\section{Introduction}

Indonesia is one of the fast developing countries in the world. One of which is the development in construction sector. Nowadays, concrete is still the most popular material used in constructing various types of structures, such as buildings, infrastructures, and many others [1-19]. Thus, it encourages the use of various cements for concrete structures. Recently, the government provides better fiscal allowance to support the rapid development of infrastructures in Indonesia. In 2015, the approval of the Revised Draft of Government Income and Budget (2015 RAPBN-P) enables the government to concentrate on realizing the infrastructure development programs, including the road and port facilities. In the subsequent years, they will eventually increase the national cement consumption, either directly from the project activities or the impact of the speedy economic growth. One type of cement that is Type-I cement or also known as the Ordinary Portland Cement (OPC) is the most widely used cement in construction. The relatively rapid development in compressive strength at the early age and high sustainable compressive strength in the long term has made it become the main option for structural needs. Another type of cement that is popularly used for recent structural needs in construction for the past two decades is the Portland Pozzolana Cement (PPC). The PPC is a mixture of Portland cement and pozzolanic ingredients such as siliceous in class-F fly ash, burnt clay, pumicite, and other by-product of power plant.

* Corresponding author: tavio_w@yahoo.com

\section{http://dx.doi.org/10.28991/cej-03091111}

$>$ This is an open access article under the CC-BY license (https://creativecommons.org/licenses/by/4.0/).

(C) Authors retain all copyrights. 
It becomes one of the most popular option of cement products used by the construction world even for structural needs. Both types of cement (OPC and PPC) have significant difference in terms of the development of compressive strength. The development of compressive strength of pozzolana cement is slightly slower than that of OPC and it gains higher compressive strength on the long run. In terms of pozzolana cement, its strength activity index can be measured and calculated in accordance with ASTM C311-17 [20] and further determined by ASTM C618-17 [21]. ASTM C595-18 [22] describes that Portland pozzolana cement is IP type and Type I (PM) where the pozzolanic content limit is between 15 and 40 percent of its total weight.

Dry-cast concrete is a production system of concrete using very low-water content or no-slump and produced using a press machine or using an external vibrator to compress it. One of the important factors that required to be considered in order to produce a solid, dense, and further impermeable or low porosity concrete is through a very good compaction and process. Figure 1 illustrates the difference between the two types of concrete (i.e. air-entrained and non-air entrained concretes) [23].

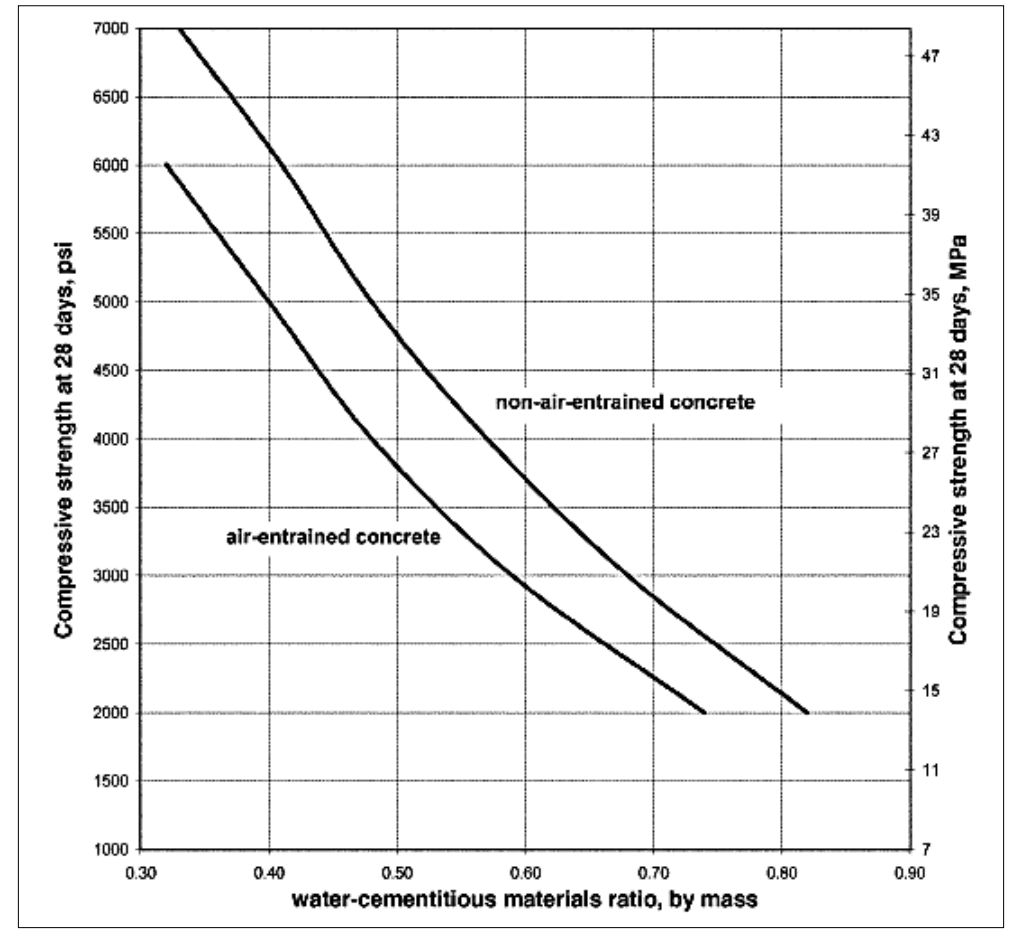

Figure 1. Water-cement ratio vs. compressive strength of concrete

The regular compaction method is the manual or machine compaction as normally used in concrete construction. The constituent material often used in the precast concrete technology is the concrete using OPC. The use of precast concrete systems offers several advantages such as rapid erection, higher quality, lower project costs, better sustainability, and improved occupational health and safety. In practice, the properties of both wet- and dry-cast concretes are very similar. Their properties such as compressive strength are significantly influenced by many factors, e.g. curing type, cement type, aggregate type, size and shape, water-cement ratio, mixing procedure, etc.

The existing mix design guidelines for designing the concrete mixture for certain compressive strength were developed previously based on the earlier research and testings of wet-cast concrete with OPC or Type-I cement. Nowadays, the application of PPC for structural concrete is becoming increasingly popular in Indonesia. Several effects arising from the use of PPC for dry-cast concrete has not been well explored as those for the wet-cast concrete. Thus, it requires further comprehensive research to resolve the current issue. Through this research, this issue is urgently required to be solved in order to discover the influence of each cement for concrete practice, particularly in precast construction using dry-cast concrete with two types of cements (OPC and PPC), such as the development of compressive strength of drycast concrete with OPC and PPC, the development of splitting tensile strength of dry-cast concrete with OPC and PPC, and the comparison between dry-and wet-cast concretes with OPC and PPC.

\section{Materials and Testing}

The materials used for making concrete, e.g. cement, aggregate, etc., are elaborated in the following sub-section. The testing procedures are also reported in the following sub-section. 


\subsection{Materials Selection}

The materials used for concrete mixture, i.e. sand and crushed stone, were collected directly from Mojokerto region. The cement used was from one of the cement factories (for both OPC and PPC). The mixing water used for making the concrete was the potable water. All the materials were selected and taken to the laboratory to undergo all the standard testing procedures to assure that they have conformed all the requirements by the standards.

\subsection{Materials Tests}

The material tests were carried out for sand, cement, crushed stone, and water using the standard testing procedures (SNI and ASTM) in Table 1. All the testing works were aimed to determine the characteristics and quality of materials used in manufacturing the concrete. This is to assure that all the concrete constituents satisfy the requirements of the standards.

Table 1. Standard's Specification, Test Method and Results of Concrete-Making Materials

\begin{tabular}{ccc}
\hline Standard's Specification & Test Method & Test Results \\
\hline ASTM C117-17 [24] & Standard Test Method for Materials Finer than 75- $\mu \mathrm{m}$ (No. 200) Sieve in Mineral & $1.17 \%$ \\
ASTM C33-18 [25] & Aggregates by Washing & $1.485 \%$ \\
ASTM C40-16 [26] & Standard Specification for Concrete Aggregates & Level 2 \\
ASTM C33-18 [25] & Standard Test Method for Organic Impurities in Fine Aggregates for Concrete & 3.12 \\
ASTM C33-18 [25] & FM for Fine Aggregate & 3.24 \\
ASTM C136-14 [27] & FM for Coarse Aggregate & Zone 3 \\
ASTM C136-14 [27] & Sieve Analysis for Fine Aggregate & Max. 20 mm \\
& Sieve Analysis for Coarse Aggregate & 2.37 \\
ASTM C128-15 [28] & Standard Test Method for Specific Gravity and Absorption of Fine Aggregate & 2.53 \\
& Bulk specific gravity (dry) & 2.81 \\
& Bulk specific gravity (SSD) & $6.62 \%$ \\
ASTM C29-17 [29] & Apparent specific gravity & $1712 \mathrm{~kg} / \mathrm{m}^{3}$ \\
& Absorption & 2.62 \\
ASTM C127-15 [30] & Standard Test Method for Bulk Density (Unit Weight) and Voids in Aggregate & 2.66 \\
& (Fine Aggregate) & 2.73 \\
ASTM C29-17 [29] & Standard Test Method for Specific Gravity and Absorption of Coarse Aggregate & 1.56 \\
ASTM C131-14 [31] & Bulk specific gravity (dry) & $1417 \mathrm{~kg} / \mathrm{m}^{3}$ \\
\hline & Bulk specific gravity (SSD) & $22.7 \%$ \\
\hline
\end{tabular}

The sieve analyses of the sand and gravel gradation are presented in Figures 2 and 3. It can concluded that the sand can be classified into Grading Zone 3. For the gravel, the sieve analysis has identified that it can be classified as coarse aggregate with the maximum size of $20 \mathrm{~mm}$.

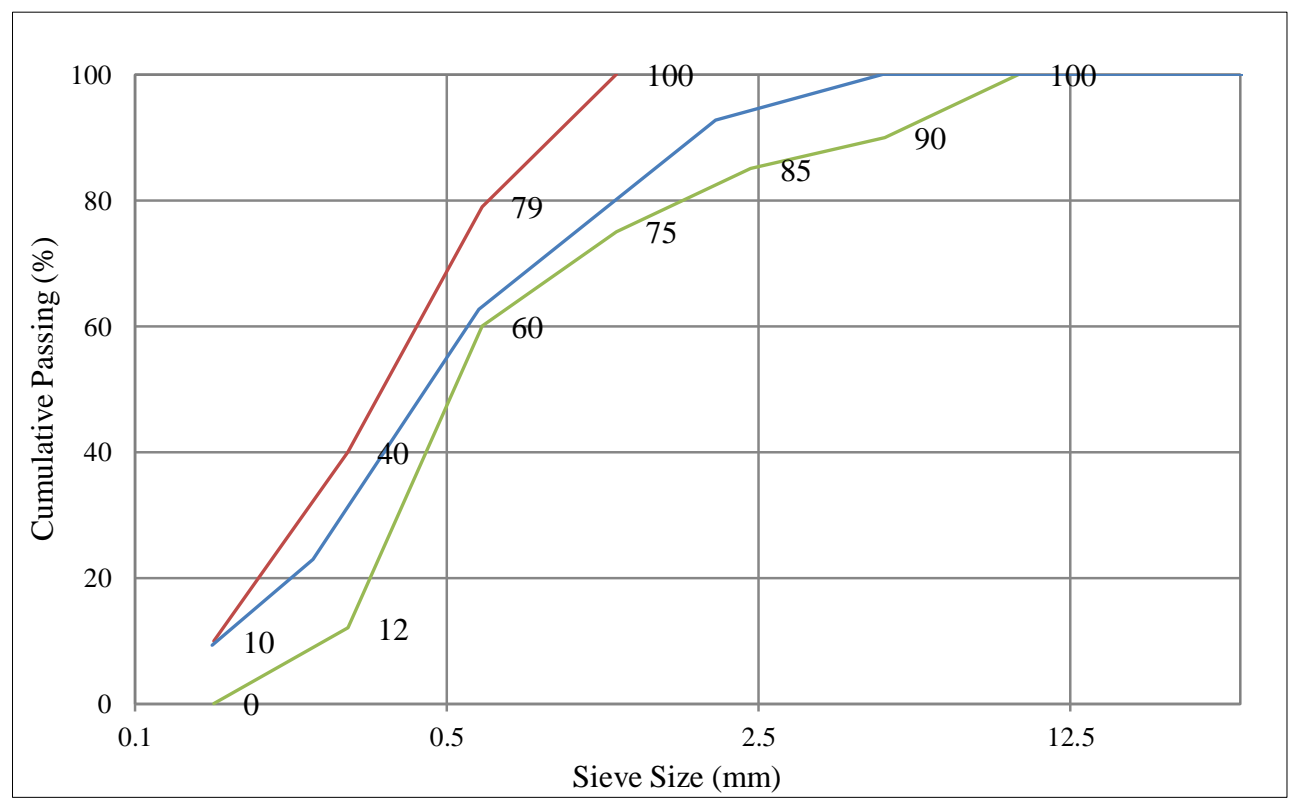

Figure 2. Grading Zone 3 for Fine Aggregate 


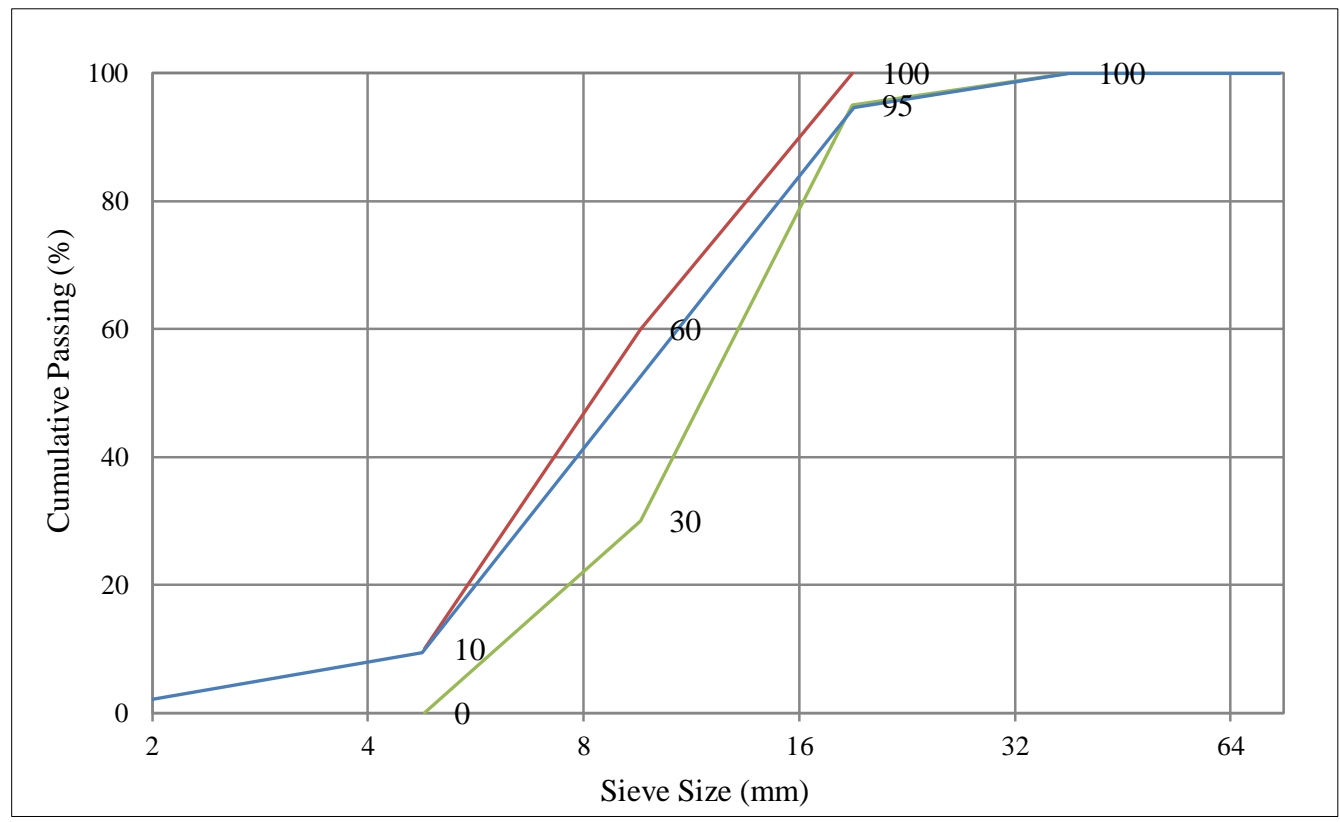

Figure 3. Grading Zone with Maximum Size of $20 \mathrm{~mm}$ for Coarse Aggregate

\subsection{Apparatus and Mix Design Procedure}

After the initial stages of material selection and laboratory tests for all materials were completed, the prior to the beginning of the concrete production or casting process, several preparation needs to be carried out, such as weighing the need of each material, preparation of the tools for mixing, casting and compaction process (e.g. concrete mixer, mixing or compaction rod, shovel, hoe, etc.) as well as lubrication of the press machine to prevent the concrete from sticking to it. In this research, the design mix method used was based on ACI 211.3R-02 [23].

\subsection{Mixing Process}

The mixing process of dry-cast concrete could be carried out by manual stirring using shovels and hoes or using a concrete mixer. The agitating process was conducted by mixing the sand and cement first, and then next mixing it with crushed stone until the mixture was uniformly homogeneous. Lastly, by the addition of a required amount of water until the mixture was evenly well distributed and uniform. Once it was completed, the concrete was ready for a hardening process.

\subsection{Vibrating and Compacting Process}

During the process of mixing the mortar, an external vibrator was also attached to the bottom of the machine and operated. The pressure of the press machine Figure 4. was applied from the top of the mold so that the concrete compacted perfectly. The pressing process was continued until the concrete was completely compact and dense. It was marked by the inability of the pressure machine to press down the concrete anymore.

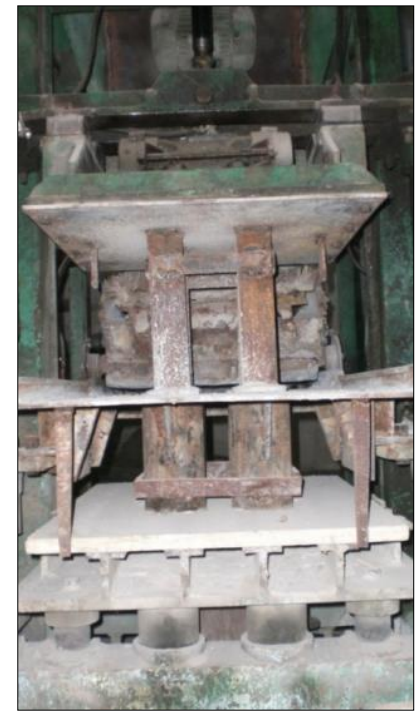

Figure 4. Production machine for dry-cast concrete 


\subsection{Finishing}

The final cast process was the process of mold removal where the concrete was released from the mold. This process was carried out by conducting the observation and measurement of the concrete that has been compacted to check if it is already in accordance with the designed size, or perhaps there are still minor damages due to the lack of compaction process. When there is a damage on the concrete specimen, then the process will be repeated all over again starting from the vibration and compaction processes until the specimen is cast perfectly as expected. The whole casting process is very quick and it only takes up about 4 to 7 minutes.

\subsection{Curing and Testing of Concrete}

The concrete curing process was performed by submerging all the concrete specimens in a water curing tank. They were then taken out and left to properly dry in air-dried-cured condition a day prior to testing process. The tests carried out were the compressive and splitting tensile strengths of concretes using OPC and PPC. The number of specimens for all the tests are given in Tables 2 and 3, and the concrete cylinder specimens are shown in Figure 5.

Table 2. Samples of Compressive Strength Test

\begin{tabular}{|c|c|c|c|c|c|c|}
\hline \multicolumn{7}{|c|}{ Diameter of Concrete Cylinder: $4 \times 8$ in } \\
\hline Age (Days) & 1 & 7 & 14 & 21 & 28 & 56 \\
\hline Total Specimen & 3 & 3 & 3 & 3 & 3 & 3 \\
\hline Variation & \multicolumn{6}{|c|}{$\begin{array}{c}w / c: 0.3,0.4,0.5 \\
\text { with OPC and PPC }\end{array}$} \\
\hline
\end{tabular}

Table 3. Samples of Splitting Tensile Strength Test

\begin{tabular}{cc}
\hline \multicolumn{2}{c}{ Diameter of Concrete Cylinder: $\mathbf{4} \times \mathbf{8}$ in } \\
\hline Age (Days) & 28 \\
Total Specimen & 24 pcs. $(4$ sample for each $w / c)$ \\
Variation & $w / c: 0.3,0.4,0.5$ \\
& with OPC and PPC \\
\hline
\end{tabular}

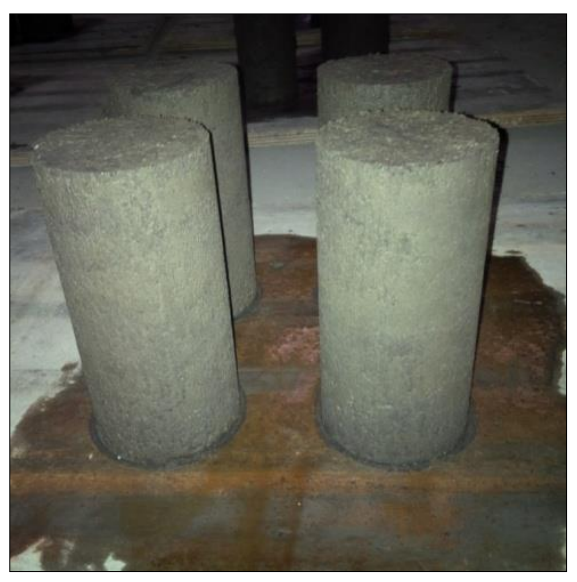

Figure 5. Concrete cylinder specimens $(4 \times 8$ in $)$

The compressive strength of the concrete cylinder specimen can be calculated by dividing the maximum load achieved by the specimen during the test by the average cross-sectional area determined as:

$$
f_{c}=\frac{P}{A}
$$

Where $\mathrm{f}_{\mathrm{c}}$ is the compressive strength of the concrete cylinder specimen $\left(\mathrm{kg} / \mathrm{cm}^{2}\right), \mathrm{P}$ is the maximum applied load indicated by the dial of the testing machine $(\mathrm{kg})$, and A is the cross-sectional area of specimen $\left(\mathrm{cm}^{2}\right)$. The test method is used to determine the compressive strength of cylindrical specimens prepared and cured in accordance with ASTM C39-18 [32].

The splitting tensile strength test method is conducted by applying the compressive force along the diameter of a cylindrical concrete specimen at a rate that is within a prescribed range until the failure occurs. This loading induces tensile stresses transversely to the plane along the direction of the applied load and relatively high compressive stresses 
in the area immediately around the applied load. The splitting tensile strength of the specimen can be calculated with the following formula:

$$
\mathrm{T}=\frac{2 \mathrm{P}}{\pi \mathrm{ld}}
$$

Where $\mathrm{T}$ is the splitting tensile strength $\left(\mathrm{kg} / \mathrm{cm}^{2}\right), \mathrm{P}$ is the maximum applied load indicated by the dial of the testing machine $(\mathrm{kg}), 1$ is the length $(\mathrm{cm})$, and $\mathrm{d}$ is the diameter of the cylindrical specimen $(\mathrm{cm})$. This test method covers the determination of the splitting tensile strength of cylindrical concrete specimens, such as molded cylinders and drilled cores in accordance with ASTM C496-17 [33]. The total specimen samples for all the compressive and splitting tensile strength tests and their corresponding ages (in days) of the specimens at the time of testing are listed in Tables 2 and 3.

\section{Results and Discussion}

\subsection{Compressive Strength of Dry-Cast Concrete}

The results and analysis carried out here is corresponding to the data obtained from the test results of the compressive strength of dry-cast concrete. Three variations of water-cement $(\mathrm{w} / \mathrm{c})$ ratios, namely $0.3,0.4$, and 0.5 , using each type of cements (OPC and PPC) were set to investigate the compressive strength growth and the differences of using the two different cement types (OPC and PPC) and also various water-cement ratios.

By using Figures 3 to 5 for various w/c ratios (i.e. 0.3, 0.4, and 0.5 , respectively) and by taking the values of concrete compressive strengths with respect to their ages, the curves which relates between the w/c ratio and the concrete compressive strength can be developed for various concrete ages. The curves generated can be used as a practical guidance for mix-designing the dry-cast concrete as shown in Figures 6, 7, and 8.

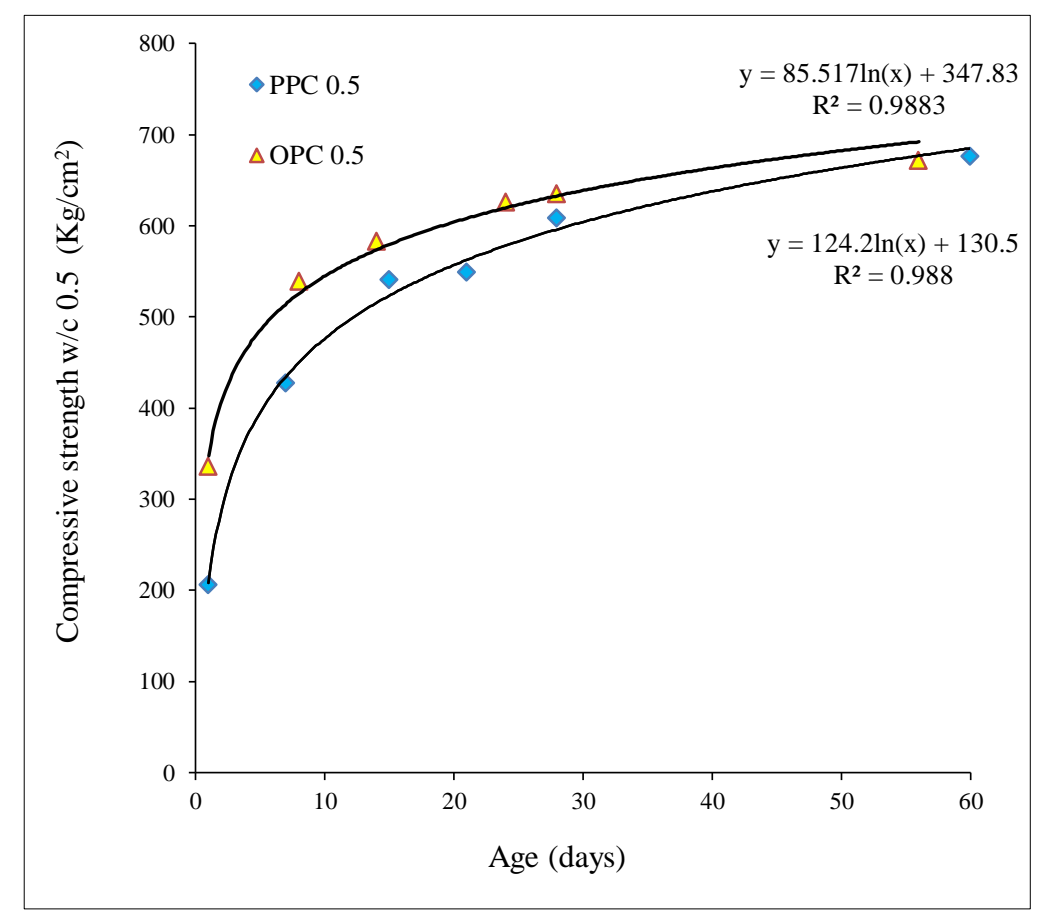

Figure 6. Compressive strengths of concrete using OPC and PPC with w/c of 0.5

As can be seen in Figure 6, the curve (compressive strength of concrete vs. age at testing) uses OPC with $0.5 \mathrm{w} / \mathrm{c}$ ratio is beyond the curve uses PPC with the same w/c ratio starting from the very beginning (at the first day) until $56^{\text {th }}$ day. At $56^{\text {th }}$ day, the values begin to close to each other and tend to be similar one to another. The compressive strength reaches almost $700 \mathrm{~kg} / \mathrm{cm}^{2}$, whereas the lowest compressive strength can be seen for that uses PPC but it is above 200 $\mathrm{kg} / \mathrm{cm}^{2}$. 


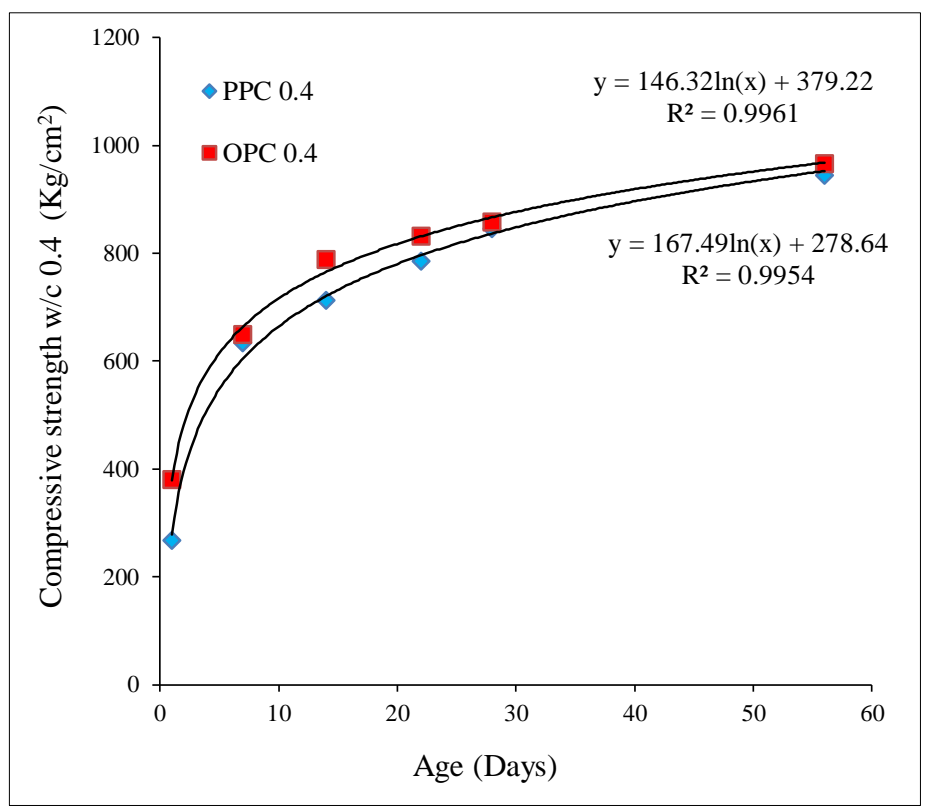

Figure 7. Compressive strengths of concrete using OPC and PPC with w/c of 0.4

In Figure 7, the curves use both OPC and PPC with water-cement (w/c) ratio of 0.4 are similar with those with w/c ratio of 0.5 . However, the values at w/c of 0.4 are even closer to each other compared with those of 0.5 w/c. At earlier age, the compressive strength reached above $900 \mathrm{~kg} / \mathrm{cm}^{2}$ compared to those of $0.5 \mathrm{w} / \mathrm{c}$, and the lowest compressive strength was found for concrete uses PPC with w/c of 0.4 which is above $220 \mathrm{~kg} / \mathrm{cm}^{2}$.

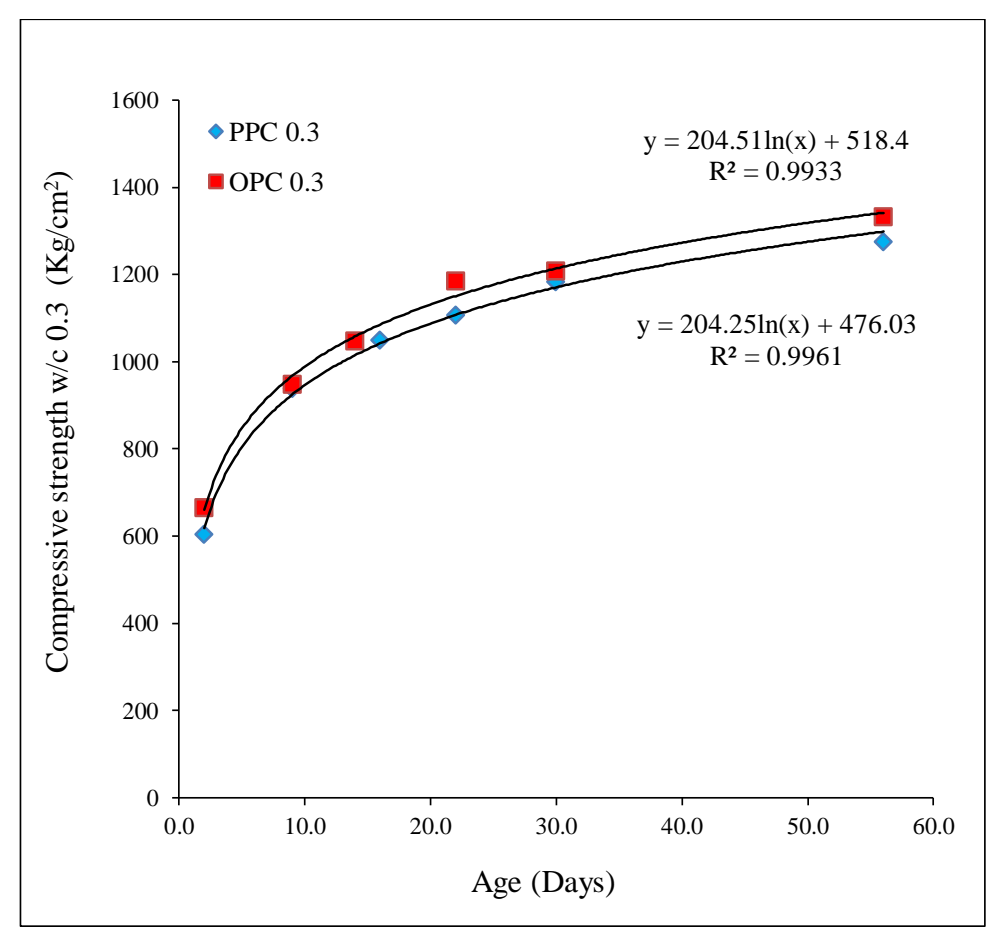

Figure 8. Compressive strengths of concrete using OPC and PPC with w/c of 0.3

The compressive strength versus age at testing curves use both OPC and PPC with $0.3 \mathrm{w} / \mathrm{c}$ ratio are given in Figure 8. The results show the difference in compressive strength values against those with 0.4 w/c ratio Figure 7 . However, the curve using OPC has shown similar trend that is higher beyond that using PPC. The addition of pozzolanic materials such as fly ash and others has impacted the development of compressive strength of concrete at early ages that is at the ages of 1 to 21 days and the values are further getting closer one to another at the age over 56 days. The highest value obtained from the test (OPC) reaches above $1199.8 \mathrm{~kg} / \mathrm{cm}^{2}$, whereas the lowest compressive strength can be seen for PPC which reaches around $600 \mathrm{~kg} / \mathrm{cm}^{2}$.

Based on the resulted curves uses OPC with various w/c ratio from 0.3 to 0.5 as shown in Figures 6 to 8 and by grouping the values of test results according to their corresponding ages, that is $1,7,14,28$, and 56 days, the new curves correlated between w/c ratio and compressive strength of concrete can be presented as in Figure 9. The function of this 
curve is to facilitate the concrete mix designer in finding and determining the compressive strength of dry-cast concrete at a certain age and further determining the w/c value or the composition for the dry-cast concrete to be made using the OPC.

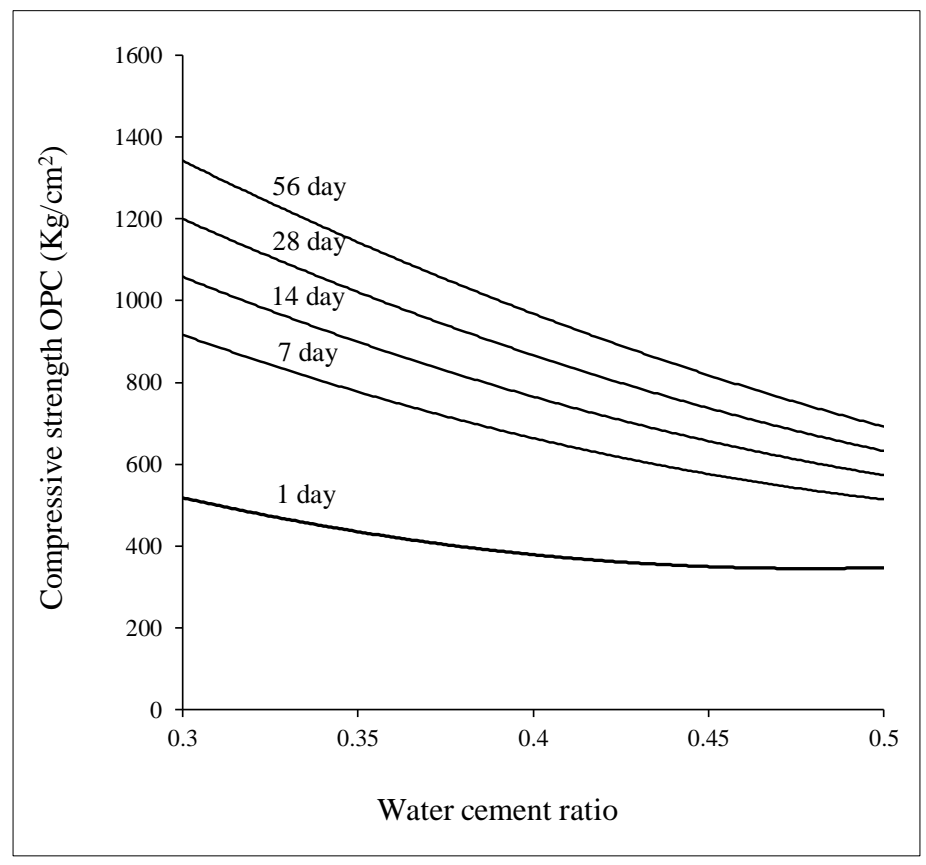

Figure 9. Compressive strength vs. w/c ratio of dry-cast concrete with OPC

Similar to the development of Figure 9 for OPC, that is also by grouping the values of test results based on their corresponding ages, i.e. 1, 7, 14, 28, and 56 days for those uses PPC (Figures 6 to 8), the new curves correlated between w/c ratio and compressive strength of concrete can be presented as in Figure 10. The curves in Figure 10 have similar function as those in Figure 9 that is to facilitate the mix design professionals in finding and determining the compressive strength of dry-cast concrete at a certain age and further determining the w/c value or the composition of the dry-cast concrete uses PPC to be mixed.

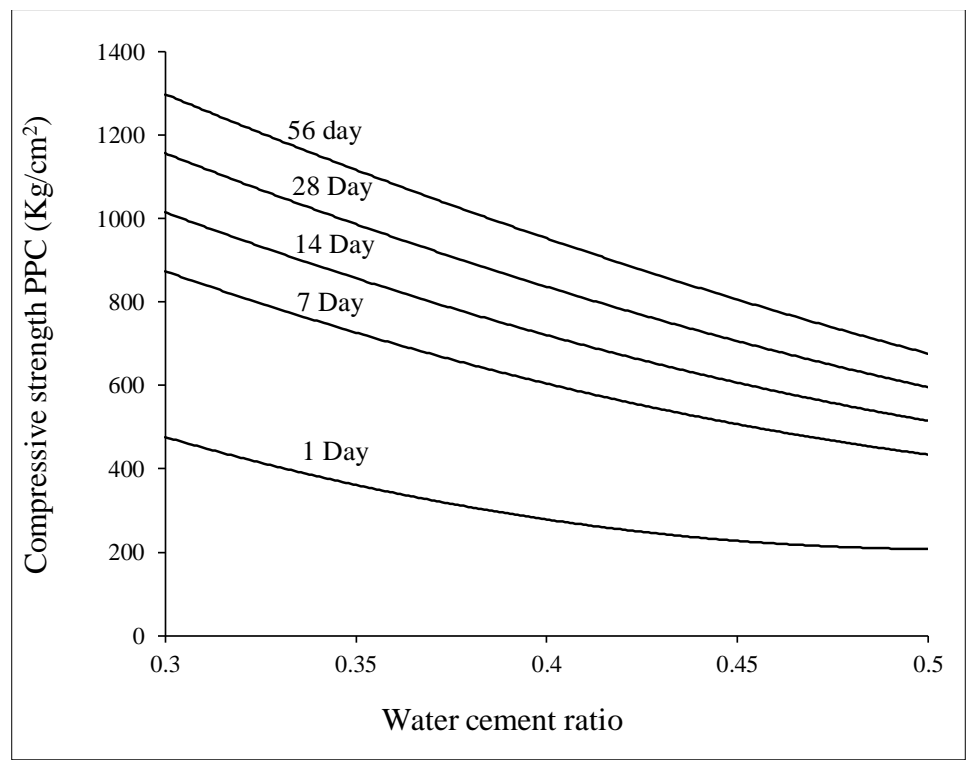

Figure 10. Compressive strength vs. w/c ratio of dry-cast concrete with PPC

\subsection{Splitting Tensile Strength of Dry-Cast Concrete}

The results and analyzes carried out in this discussion are only from the test data at 28 days of age of the dry-cast concrete with three different variations of w/c ratios $(0.3,0.4$, and 0.5$)$ using both OPC and PPC to observe the strength development and the influence of using different types of cement (OPC and PPC) and also the effect of w/c ratio to the compressive strength of concrete as can be seen in Figure 11. 


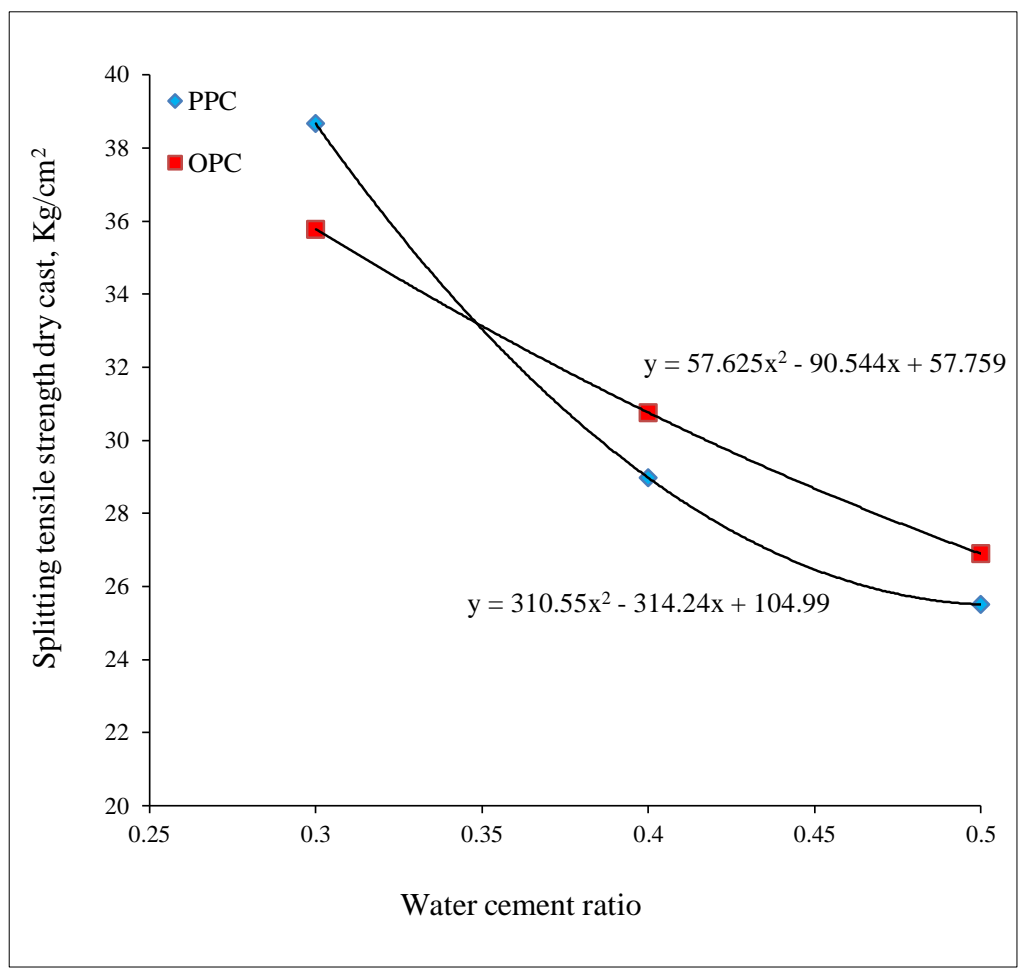

Figure 11. Comparison of splitting tensile strength of dry-cast concrete with OPC and PPC

The relationship between the concrete compressive strength and the ratio of concrete compressive/splitting tensile strength can be drawn based on the previous analysis as shown in Figure 12. It can be seen that there are significant differences in the ratio of $f_{\text {tsp }} / \mathrm{f}_{\mathrm{c}}$ above 60 up to $80 \mathrm{MPa}$ for both types of cements (OPC and PPC). The curve for drycast concrete with PPC is lower than that with OPC. Referring to the results from several researchers, e.g. Raphael [34], Gardner [35], Oluokun et al. [36], Arioglu et al. [37], Mokhtarzadeh and French [38], ACI 318M-14 [39], ACI 363R10 [40], and CEB-FIB provisions [41] in Table 4, it can be concluded that dry-cast concrete provides higher strength in both compression and splitting tensile strengths.

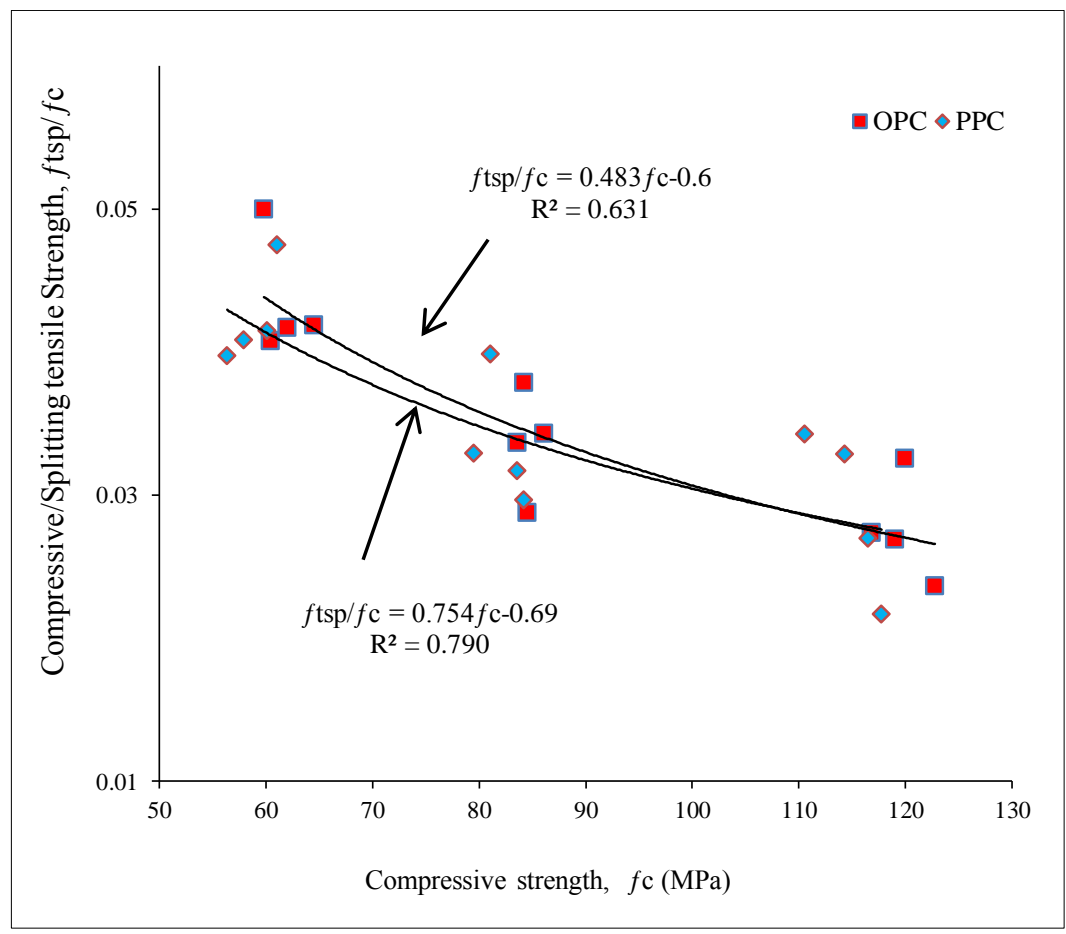

Figure 12. Relationship between compressive/splitting tensile strength and compressive strength of dry-cast concrete with OPC and PPC 
Table 4. Relationships between Splitting Tensile and Compressive Strengths for Several Concrete Strength Ranges

\begin{tabular}{|c|c|c|c|}
\hline Reference & Equation & Range (MPa) & Remarks \\
\hline ACI 363R-10 [40] & $\mathrm{f}_{\mathrm{tsp}}=0.59 \mathrm{fc}^{0.5}$ & $21 \leq f_{\mathrm{c}} \leq 83$ & - \\
\hline ACI 318M-14 [39] & $\mathrm{f}_{\mathrm{tsp}}=0.56 \mathrm{fc}^{0.5}$ & - & - \\
\hline CEB-FIB [41] & $f_{\text {tsp }}=0.3 \mathrm{fc}^{\frac{2}{3}}$ & $f_{\mathrm{c}}<83$ & - \\
\hline $\begin{array}{l}\text { Mokhtarzadeh and } \\
\text { French [38] }\end{array}$ & $\begin{array}{c}f_{\mathrm{tsp}}=0.56 f \mathrm{fc}^{0.5} \& \\
\mathrm{f}_{\mathrm{tsp}}=0.32 \mathrm{fc}^{0.63}\end{array}$ & $48 \leq f_{\mathrm{c}} \leq 103$ & For all data, moist and heat-cured \\
\hline Raphael [34] & $f_{\text {tsp }}=0.313 \mathrm{fc}^{0.667}$ & $\mathrm{f}_{\mathrm{c}} \leq 40$ & Normal weight concrete \\
\hline \multirow{2}{*}{ Gardner [35] } & $f_{\text {tsp }}=0.47 \mathrm{fc}^{0.59}$ & $3 \leq \mathrm{f}_{\mathrm{c}} \leq 46$ & Type I cement concrete $(\mathrm{r}=0.865)$ \\
\hline & $f_{\text {tsp }}=0.46 f c^{0.60}$ & $13 \leq f_{\mathrm{c}} \leq 72$ & Type III cement concrete $(r=0.989)$ \\
\hline Oluokun et al. [36] & $f_{\mathrm{tsp}}=0.294 \mathrm{fc}_{\mathrm{c}}^{0.69}$ & $3.5 \leq f_{\mathrm{c}} \leq 63$ & Normal weight concrete $(\mathrm{IAE}=7.43 \%)$ \\
\hline Arioglu et al. [37] & $\frac{f_{\text {tsp }}}{f c}=0.387 f c^{-0.37}$ & $4<f_{c}<120$ & $\begin{array}{l}\text { For }\left(0 \text { to } 30^{\circ} \mathrm{C}\right) \text { curing temperatures, Type I, III } \\
\text { cements, fly ash, bottom ash, silica fume concrete }\end{array}$ \\
\hline \multirow{2}{*}{ Proposed Equations } & $\frac{f_{\text {tsp }}}{f c}=0.754 \mathrm{fc}^{-0.69}$ & $60 \leq f_{\mathrm{c}} \leq 119$ & Normal Dry Cast Concrete, Type I cement/OPC \\
\hline & $\frac{f_{\text {tsp }}}{f c}=0.483 f^{-0.6}$ & $60 \leq f_{\mathrm{c}} \leq 114$ & Normal Dry Cast Concrete, PPC \\
\hline
\end{tabular}

\section{Conclusions}

From the results and analysis of the research conducted in the study, the following conclusions can be drawn:

1) The results of the compressive strength test $f_{\mathrm{c}}$ of dry-cast concrete with various w/c, i.e. $0.3,0.4$, and 0.5 using OPC and PPC were found to have significant differences which lies in the early age, that is at the ages of 1 to 21 days.

2) The compressive strengths of dry-cast concrete with OPC for various w/c ratio and ages are entirely higher than those with PPC. The maximum compressive strength was found at age of 28 days with w/c of 0.3 which can reach up to $1199.8 \mathrm{~kg} / \mathrm{cm}^{2}$.

3) The dry-cast concrete has been proven to be very effective in terms of production speed, i.e. rapid casting speed and efficiency of the use of formwork or mold which only requires one or two items. Each cast only need 3 to 15 minutes according to the specimen or product size.

4) The relationships between w/c and the compressive strength of dry-cast concretes at 28 days with OPC and PPC are $f_{\mathrm{c}}=4958 \mathrm{x}^{2}-6802 \mathrm{x}+2794$ and $f_{\mathrm{c}}=3964 \mathrm{x}^{2}-5975 \mathrm{x}+2592$, respectively.

5) The dry-cast concretes with extremely dry condition using both OPC (Type-I cement) and PPC have very much higher compressive strengths (above $492.5 \mathrm{~kg} / \mathrm{cm}^{2}$ ) as compared to the wet-cast concrete from the ACI curves which provides only two curves with respect to non-air-entrained and air-entrained concretes.

6) The results of splitting tensile strength tests of dry-cast concrete showed a significant increase particularly those with PPC, starting from the lowest to the highest $\mathrm{w} / \mathrm{c}$ of 0.5 to 0.3 . The splitting tensile strength value, $f_{\text {tsp }}$ at age of 28 days can reach up to $38.6 \mathrm{~kg} / \mathrm{cm}^{2}$.

7) The relationships between the compressive and the splitting tensile strengths of dry-cast concrete can be given as follows:

$$
\text { OPC: } \quad f_{\text {tsp }} / f_{\mathrm{c}}=0.754 f \mathrm{c}^{-0.69} \quad \text { PPC: } \quad f_{\text {tsp }} / f_{\mathrm{c}}=0.483 f \mathrm{c}^{-0.6}
$$

\section{Acknowledgment}

The authors would like to gratefully acknowledge PT. Arga Beton Indah for permitting the authors to use their facilities in the plant in preparing all the dry-cast concrete specimens.

\section{References}

[1] Tavio; Kusuma, B.; and Suprobo, P., "Experimental Behavior of Concrete Columns Confined by Welded Wire Fabric as Transverse Reinforcement under Axial Compression,” ACI Structural Journal, American Concrete Institute, Vol. 109, No. 3, pp. 339-348, May-June 2012, doi.org/10.14359/51683747. 
[2] Pudjisuryadi, P.; Tavio; and Suprobo, P., "Performance of Square Reinforced Concrete Columns Externally Confined by Steel Angle Collars under Combined Axial and Lateral Load," Procedia Engineering, Elsevier, Vol. 125, pp. 1043-1049, 2015, doi.org/10.1016/j.proeng.2015.11.160.

[3] Tavio; Suprobo, P.; and Kusuma, B., "Ductility of Confined Reinforced Concrete Columns with Welded Reinforcement Grids," Excellence in Concrete Construction through Innovation-Proceedings of the International Conference on Concrete Construction, pp. 339-344, CRC Press, Taylor and Francis Group, London, UK, 2009, doi.org/10.1201/9780203883440.ch51.

[4] Kusuma, B.; Tavio; and Suprobo, P., "Axial Load Behavior of Concrete Columns with Welded Wire Fabric as Transverse Reinforcement,” Procedia Engineering, Elsevier, Vol. 14, pp. 2039-2047, 2011, doi.org/10.1016/j.proeng.2011.07.256.

[5] Tavio; Kusuma, B.; and Suprobo, P., "Investigation of Stress-Strain Models for Confinement of Concrete by Welded Wire Fabric," Procedia Engineering, Elsevier, Vol. 14, pp. 2031-2038, 2011, doi.org/10.1016/j.proeng.2011.07.255.

[6] Tavio; and Kusuma, B., "Stress-Strain Model for High-Strength Concrete Confined by Welded Wire Fabric," Journal of Materials in Civil Engineering, American Society of Civil Engineers, Vol. 21, No. 1, pp. 40-45, January 2009, doi.org/10.1061/(asce)08991561(2009)21:1(40).

[7] Tavio; Anggraini, R.; Raka, I G. P.; and Agustiar, "Tensile Strength/Yield Strength (TS/YS) Ratios of High-Strength Steel (HSS) Reinforcing Bars," AIP Conference Proceedings, American Institute of Physics, Vol. 1964, pp. 020036-1-020036-8, 2018, doi.org/10.1063/1.5038318.

[8] Tavio; Suprobo, P.; and Kusuma, B., "Strength and Ductility Enhancement of Reinforced HSC Columns Confined with HighStrength Transverse Steel," Proceedings of the Eleventh East Asia-Pacific Conference on Structural Engineering and Construction (EASEC-11), pp. 350-351, Taipei, Taiwan, November 2008.

[9] Anggraini, R.; Tavio; Raka, I G. P.; and Agustiar, "Stress-Strain Relationship of High-Strength Steel (HSS) Reinforcing Bars," AIP Conference Proceedings, American Institute of Physics, Vol. 1964, pp. 020025-1-020025-8, 2018, doi.org/10.1063/1.5038307.

[10] Ahmad, H. H.; and Tavio, "Experimental Study of Cold-Bonded Artificial Lightweight Aggregate Concrete," AIP Conference Proceedings, American Institute of Physics, Vol. 1977, pp. 030011-1-030011-8, 2018, doi.org/10.1063/1.5042931.

[11] Pudjisuryadi, P.; Tavio; and Suprobo, P., “Axial Compressive Behavior of Square Concrete Columns Externally Collared by Light Structural Steel Angle Sections," International Journal of Applied Engineering Research, Research India Publications, Vol. 11, No. 7, pp. 4655-4666, 2016.

[12] Sabariman, B.; Soehardjono, A.; Wisnumurti; Wibowo, A.; and Tavio, "Stress-Strain Behavior of Steel Fiber-Reinforced Concrete Cylinders Spirally Confined with Steel Bars," Advances in Civil Engineering, Hindawi, Vol. 2018, pp. 1-8, 2018, doi.org/10.1155/2018/6940532.

[13] Astawa, M. D.; Raka, I G. P.; and Tavio, "Moment Contribution Capacity of Tendon Prestressed Partial on Concrete BeamColumn Joint Interior According to Provisions ACI 318-2008 Chapter 21.5.2.5(c) Due to Cyclic Lateral Loads," MATEC Web of Conferences, EDP Sciences, Vol. 58, No. 04005, pp. 1-8, 2016, doi.org/10.1051/matecconf/20165804005.

[14] Tavio; and Parmo, “A Proposed Clamp System for Mechanical Connection of Reinforcing Steel Bars,” International Journal of Applied Engineering Research, Research India Publications, Vol. 11, No. 11, pp. 7355-7361, 2016.

[15] Raka, I G. P.; Tavio; and Astawa, M. D., "State-of-the-Art Report on Partially-Prestressed Concrete Earthquake-Resistant Building Structures for Highly-Seismic Region," Procedia Engineering, Elsevier, Vol. 95, pp. 43-53, 2014, doi.org/10.1016/j.proeng.2014.12.164.

[16] Tavio; and Teng, S., "Effective Torsional Rigidity of Reinforced Concrete Members," ACI Structural Journal, American Concrete Institute, Vol. 101, No. 2, pp. 252-260, March-April 2004, doi.org/10.14359/13023.

[17] Tavio, "Interactive Mechanical Model for Shear Strength of Deep Beams," Journal of Structural Engineering, American Society of Structural Engineers, Vol. 132, No. 5, pp. 826 -827, May 2006, doi.org/10.1061/(asce)0733-9445(2006)132:5(826).

[18] Raharjo, D.; Subakti, A.; and Tavio, "Mixed Concrete Optimization Using Fly Ash, Silica Fume and Iron Slag on the SCC's Compressive Strength,” Procedia Engineering, Elsevier, Vol. 54, pp. 827-839, 2013, doi.org/10.1016/j.proeng.2013.03.076.

[19] Astawa, M. D.; Tavio; and Raka, I G. P., "Ductile Structure Framework of Earthquake Resistant of High-Rise Building on Exterior Beam-Column Joint with the Partial Prestressed Concrete Beam-Column Reinforced Concrete," Procedia Engineering, Elsevier, Vol. 54, pp. 413-427, 2013, doi.org/10.1016/j.proeng.2013.03.037.

[20] ASTM Subcommittee C09.24, "Standard Test Methods for Sampling and Testing Fly Ash or Natural Pozzolans for Use in Portland-Cement Concrete (ASTM C311/C311M-17),” ASTM International, 2017, doi.org/10.1520/C0311_C0311M-17.

[21] ASTM Subcommittee C09.24, "Standard Specification for Coal Fly Ash and Raw or Calcined Natural Pozzolan for Use in Concrete (ASTM C618-17a),” ASTM International, 2017, doi.org/10.1520/C0618-17A.

[22] ASTM Subcommittee C01.10, "Standard Specification for Blended Hydraulic Cements (ASTM C595/C595M-18)," ASTM International, 2018, doi.org/10.1520/C0595_C0595M-18.

[23] ACI Committee 211, "Guide for Selecting Proportions for No-Slump Concrete (ACI 211.3R-02)," American Concrete Institute, 2002, 26 pp.

[24] ASTM Subcommittee C09.20, "Standard Test Method for Materials Finer than 75- $\mu \mathrm{m}$ (No. 200) Sieve in Mineral Aggregates by Washing (ASTM C117-17),” ASTM International, 2017, doi.org/10.1520/C0117-17. 
[25] ASTM Subcommittee C09.20, "Standard Specification for Concrete Aggregates (ASTM C33/C33M-18)," ASTM International, 2018, doi.org/10.1520/C0033_C0033M-18.

[26] ASTM Subcommittee C09.20, "Standard Test Method for Organic Impurities in Fine Aggregates for Concrete (ASTM C40/C40M-16)," ASTM International, 2016, doi.org/10.1520/C0040_C0040M-16.

[27] ASTM Subcommittee C09.20, "Standard Test Method for Sieve Analysis of Fine and Coarse Aggregates (ASTM C136/C136M14),” ASTM International, 2014, doi.org/10.1520/C0136_C0136M-14.

[28] ASTM Subcommittee C09.20, "Standard Test Method for Relative Density (Specific Gravity) and Absorption of Fine Aggregate (ASTM C128-15)," ASTM International, 2015, doi.org/10.1520/C0128-15.

[29] ASTM Subcommittee C09.20, "Standard Test Method for Bulk Density ("Unit Weight") and Voids in Aggregate (ASTM C29/C29M-17a)," ASTM International, 2017, doi.org/10.1520/C0029_C0029M-17A.

[30] ASTM Subcommittee C09.20, "Standard Test Method for Relative Density (Specific Gravity) and Absorption of Coarse Aggregate (ASTM C127-15),” ASTM International, 2015, doi.org/10.1520/C0127-15.

[31] ASTM Subcommittee C09.20, "Standard Test Method for Resistance to Degradation of Small-Size Coarse Aggregate by Abrasion and Impact in the Los Angeles Machine (ASTM C131/C131M-14)," ASTM International, 2014, doi.org/10.1520/C0131_C0131M-14.

[32] ASTM Subcommittee C09.61, "Standard Test Method for Compressive Strength of Cylindrical Concrete Specimens (ASTM C39/C39M-18)," ASTM International, 2018, doi.org/10.1520/C0039_C0039M-18.

[33] ASTM Subcommittee: C09.61, "Standard Test Method for Splitting Tensile Strength of Cylindrical Concrete Specimens (ASTM C496/C496M-17),” ASTM International, 2017, doi.org/10.1520/C0496_C0496M-17.

[34] Raphael, J. M., “Tensile Strength of Concrete,” ACI Journal, Proceedings, V. 81, No. 2, Mar.-Apr. 1984, pp. 158-165, doi.org/10.14359/10653 .

[35] Gardner, N. J., "Effect of Temperature on the Early-Age Properties of Type I, Type III, and Type I/Fly Ash Concretes," ACI Materials Journal, V. 87, No. 1, Jan.-Feb. 1990, pp. 68-78, doi.org/10.14359/2381.

[36] Oluokun, F. A.; Burdette, E. G.; and Deatherage, J. H., "Splitting Tensile Strength and Compressive Strength Relationships at Early Ages,” ACI Materials Journal, V. 88, No. 2, Mar.-Apr. 1991, pp. 115-121, doi.org/10.14359/1859.

[37] Arioglu, N.; Girgin, Z. C.; and Arioglu, E., "Evaluation of Ratio between Splitting Tensile Strength and Compressive Strength for Concretes up to $120 \mathrm{MPa}$ and its Application in Strength Criterion," ACI Materials Journal, V. 103, No. 1, Jan.-Feb. 2006, pp. 18-24, doi.org/10.14359/15123.

[38] Mokhtarzadeh, A.; and French, C., "Mechanical Properties of High Strength Concrete with Consideration for Precast Applications," ACI Materials Journal, V. 97, No. 2, Mar.-Apr. 2000, pp. 136-147, doi.org/10.14359/816.

[39] ACI Committee 318, "Building Code Requirements for Structural Concrete (ACI 318M-14) and Commentary (ACI 318RM14)," American Concrete Institute, 2014, 519 pp.

[40] ACI Committee 363, “Report on High-Strength Concrete (ACI 363R-10),” American Concrete Institute, 2010, 65 pp.

[41] Comite European du Béton/Fédération Internationale de laPrecontrainte, "CEB-FIP Model Code for Concrete Structures 1990: Evaluation of the Time Dependent Behaviour of Concrete," Bulletin d'Information No. 199, Lausanne, 1991,201 pp., doi.org/10.1680/ceb-fipmc1990.35430. 